Eur. J. Clin. Chem. Clin. Biochem.

Vol. 31, 1993, pp. 5-16

(C) 1993 Walter de Gruyter \& Co.

Berlin - New York

\title{
The Measurement of Enzyme Activities in the Resting Human Polymorphonuclear Leukocyte - Critical Estimate of a Method
}

\author{
By U. Fauth, T. Schlechtriemen, W. Heinrichs, Inés Puente-Gonzalez and M. Halmágyi
}

Klinik für Anästhesiologie der Johannes Gutenberg-Universität Mainz

(Received May 27/September 29, 1992)

Summary: As a system for study, the isolated human polymorphonuclear leukocyte combines the advantages of a quasi-non-invasive preparation with a nearly complete complement of enzymes of carbohydrate and energy metabolism. However, small sample volumes and, in some cases, very low enzyme activities make high demands on sample processing, storage, and performance of continuous measurements, if the enzyme activities are to be measured with acceptable reproducibility. In the presented study several aspects of homogenization, storage, and continuous measurement were scrutinized, to identify critical steps and consider ways of optimizing the method.

Polymorphonuclear leukocytes were separated from the blood of healthy subjects by sedimentation and density gradient centrifugation. After ultrasonic homogenization, 13 enzymes of glycolysis and gluconeogenesis, the tricarboxylic acid cycle, and glycogen metabolism were determined photometrically. The variation of several conditions showed:

1. The duration of exposure to ultrasound for the homogenization of polymorphonuclear leukocytes has no influence over a wide range of time.

2. Addition of the detergents Triton $\mathrm{X}-100$ and deoxycholic acid, as well as the SH-group protector dithiothreitol, to the homogenizing medium increased the measured activities of only a few enzymes.

3. Considerable inaccuracy was encountered.when the suspension was divided into parts for homogenization with different additives; such splitting of the suspension should therefore be performed only when necessary, as in the determination of reference values (e.g. protein or DNA content of the cell suspension).

4. Twenty four-fold determination of enzyme activities from one homogenate resulted in precisions between $4.5 \%$ (citrate synthase) and $14.4 \%$ (transketolase), which is satisfactory for the low activities (as low as $1 \mathrm{U} / \mathrm{l})$ in the homogenate.

5. The reproducibility of enzyme activities, measured in homogenates of polymorphonuclear leukocytes from different blood samples drawn simultaneously, was only slightly worse than that of the continuous measurement method itself. Thus, the precision of the measurement of enzyme activity seems to be the main determinant of the overall method.

In conclusion, the described procedure of separation, homogenization, and enzyme measurement in human polymorphonuclear leukocyte meets the requirements of biochemical or clinical trials and can be recommended for clinical metabolic studies.

\section{Introduction}

Together with the systematic development of methods for the rapid and reliable separation of the subclasses of white blood cells from whole blood (1), the study of the metabolism of the human polymorphonuclear leukocyte has found wide application in theoretical and clinical research. A distinction must be drawn between the investigation of cell function and metab-

Eur. J. Clin. Chem. Clin. Biochem. / Vol. 31, 1993 / No. 1 
olism of intact polymorphonuclear leukocytes and studies on homogenized cells. In particular, the measurement of metabolite concentrations and enzyme activities in leukocyte homogenates is used in the investigation of metabolism and in the differentiation of pathological white blood cells $(2-5)$.

A great number of studies take advantage of the fact that the polymorphonuclear leukocyte has a complete complement of the enzymes involved in the main metabolic pathways of the cell (6). The short life time of the polymorphonuclear leukocytes of 9-14 days (7) ensures a rapid adaption to changing metabolic conditions. Therefore, the polymorphonuclear leukocytes can be used as an easily accessible cellular model, which, to a certain extent, reflects alterations in the whole organism. For example, alterations of the maximal rates of substrate turnover of enzymes of carbohydrate metabolism measured in the homogenate of polymorphonuclear leukocytes separated from traumatized patients can be interpreted in the sense of well known metabolic adaptions of the posttraumatic period (8). Typical changes of enzyme activities have also been described for polymorphonuclear leukocytes of uraemic patients $(9,10)$ and for infants that are small for their gestational age (11).

Measurement of the enzyme activities of homogenized polymorphonuclear leukocytes involves specific problems, which must be critically resolved, if the method is to be applied in clinical studies.

Inevitably, in all investigations using isolated polymorphonuclear leukocytes, the volume of tissue available is very small compared with tissue samples obtained bioptically. Even with optimized separation methodology, the yield of polymorphonuclear leukocytes is about $25 \%$ of the total polymorphonuclear leukocyte content of the blood sample, corresponding to 0.5 to $5 \mathrm{ml}$ suspension with a protein content of about $1 \mathrm{~g} / \mathrm{l}$ from $20 \mathrm{ml}$ blood (all count $20 \times 10^{\circ} / 1$ ).

Measurement of the activities of a large number of enzymes in a sample with a relatively low content of protein means that the measured activities are low. Since the sample activities are related to a fix quantity, e. g. the protein or DNA content, inaccuracies of the measurement are aggravated by possibly unrepresentative splitting of the cell suspension for the additional analyses.

The aim of this study is the presentation of a procedure for the measurement of 13 enzymes of carbohydrate and energy metabolism in isolated and homogenized polymorphonuclear leukocytes. In particular, the application of standard methods for cell processing and enzyme measurement to the human granulocyte are analysed critically, because there is no literature dealing with the systematic investigation of this cell. In detail, an examination of the following topics seems to be essential:

1. The error caused by splitting the polymorphonuclear leukocyte suspension for the determination of reference substance concentration (protein or DNA);

2. The influence of the technique of ultrasonic homogenization of the suspension on the detectable enzyme activities;

3. The influence of the milieu during homogenization;

4. The stability of the homogenate in the period between thawing and photometry;

5. The reproducibility of the photometric enzyme measurements, as well as the reproducibility of the overall method including separation, homogenization, storage, and enzyme measurement.

Optimization of all conditions should result in improved reproducibility of the measured activities, which ultimately means a better statistical differentiation in studies using this model.

\section{Methods}

All studies were performed using polymorphonuclear leukocyte suspensions isolated from 20 to $40 \mathrm{ml}$ of blood from healthy donors.

\section{Enzymes}

Unless stated otherwise, the methodical investigations were performed on the following enzymes'): lactate dehydrogenase, malate dehydrogenase, isocitrate dehydrogenase, glucose-6phosphate dehydrogenase, lipoamide dehydrogenase, transke-

1) List of Enzymes

\begin{tabular}{|c|c|c|}
\hline Trivial Name & Systematic Name & $\begin{array}{l}\text { EC } \\
\text { Number }\end{array}$ \\
\hline Lactate dehydrogenase & Lactate dehydrogenase & 1.1.1.27 \\
\hline Malate dehydrogenase & Malate dehydrogenase & 1.1.1.37 \\
\hline Isocitrate dehydrogenase & $\begin{array}{l}\text { Isocitrate } \\
\text { dehydrogenase }\end{array}$ & 1.1.1.42 \\
\hline $\begin{array}{l}\text { Glucose-6-phosphate de- } \\
\text { hydrogenase }\end{array}$ & $\begin{array}{l}\text { Glucose-6-phosphate } \\
\text { dehydrogenase }\end{array}$ & 1.1.1.49 \\
\hline $\begin{array}{l}\text { Lipoamide } \\
\text { dehydrogenase }\end{array}$ & $\begin{array}{l}\text { Lipoamide } \\
\text { dehydrogenase }\end{array}$ & 1.6.4.3 \\
\hline Transketolase & Transketolase & 2.2.1.1 \\
\hline Phosphorylase a & Phosphorylase a & 2.4 .1 .1 \\
\hline Hexokinase & Hexokinase & 2.7.1.1 \\
\hline Pyruvate kinase & Pyruvate kinase & 2.7.1.40 \\
\hline Adenylate kinase & Adenylate kinase & 2.7.4.3 \\
\hline $\begin{array}{l}\text { Fructose-1,6- } \\
\text { diphosphatase }\end{array}$ & Hexosediphosphatase & 3.1.3.11 \\
\hline $\begin{array}{l}\text { Fructose-di-phosphate } \\
\text { aldolase }\end{array}$ & $\begin{array}{l}\text { Fructosediphosphate } \\
\text { aldolase }\end{array}$ & 4.1.2.13 \\
\hline Citrate synthase & Citrate synthase & 4.1.3.7 \\
\hline
\end{tabular}


tolase, phosphorylase a, hexokinase, pyruvate kinase, adenylate kinasc, fructosc-1,6-diphosphatase, fructose-di-phosphate aldolase, citrate synthase (cf. fig. 1).

\section{Isolation of polymorphonuclear leukocytes}

The isolation of polymorphonuclear leukocytes is based on the principle of accelerated erythrocyte sedimentation and density gradient centrifugation, developed by Böyum and modified by Metcoff \& Distler $(1,12)$. The blood sample, anticoagulated by heparin, is mixed with dextran to accelerate the agglomeration and sedimentation of erythrocytes. Sedimentation is followed by the separation of polymorphonuclear leukocytes by centrifugation of the leukocyte-rich plasma $(350 \mathrm{~g}, 25 \mathrm{~min})$ on Ficoll 1077 (Histopaque 1077, Sigma 1077-1). Remaining erythrocytes are removed by hypotonic lysis (addition of water and reconstitution of isotonic milieu by $\mathrm{NaCl} 600 \mathrm{mmol} / \mathrm{l}$ after 30 to 45 seconds). After two-fold rinsing in Hank's buffer solution $\left(\mathrm{Na}^{+}\right.$ $140, \mathrm{~K}^{+} 5.3, \mathrm{Mg}^{2+} 3.2, \mathrm{HPO}_{4}^{2-} 0.69, \mathrm{H}_{2} \mathrm{PO}_{4}^{-} 0.88, \mathrm{SO}_{4}^{2-} 3.2$ $\mathrm{mmol} / \mathrm{l})$ polymorphonuclear leukocytes are finally suspended in $\mathrm{KCl} 0.14 \mathrm{~mol} / \mathrm{l}$. For present purposes, the density of the cell suspension was adjusted (by optical absorbance) to a final count of about $20 \cdot 10^{\circ} / 1$ by addition of $\mathrm{KCl} 0.14 \mathrm{~mol} / 1$. The purity of the polymorphonuclear leukocyte preparation regularly amounts to $95 \%$. Vitality was checked by dye exclusion (trypan blue $50 \mathrm{~g} / \mathrm{l}$ in potassium phosphate buffer $0.1 \mathrm{~mol} / \mathrm{l}$ ) and ranged between 85 and $97 \%$. When required, a sample was taken before further processing of the suspension for the determination of protein content according to Lowry et al. (13). All procedures were performed using ice cold solutions and cooling centrifuges $\left(2-4^{\circ} \mathrm{C}\right)$; room cooling was not considered to be necessary. The final suspensions were mixed $1+1$ with different buffers and homogenized on ice by ultrasound. After centrifugation $(6000 \mathrm{~g}, 10 \mathrm{~min})$ the supernatant was used for further analysis.

\section{Homogenization medium}

Four buffers were tested. To a glycerol containing buffer (standard buffer, 'buffer ST'; glycerol 1350, glycyl-glycine 100 , EDTA-Na 1 , NADH-Na $0.05 \mathrm{mmol} / \mathrm{l}$, bovine serum albumin $0.2 \mathrm{~g} / \mathrm{l})$, dithiothreitol (4 mmol/l, 'buffer DTT'), Triton X-100 (1 mmol/l, 'buffer TX') or deoxycholic acid ( $5 \mathrm{mmol} / \mathrm{l}$, 'buffer DOC') was added. The preparation was split into twelve parts, which were homogenized separately using the 4 different buffers. As only the comparison of the homogenizing medium was of interest, the determination of the protein content of the 12 different suspensions was dispensed with.

\section{Ultrasonic homogenization}

All samples were homogenized ultrasonically (Labsonic, Fa. Braun) on ice, with a power of $50 \mathrm{~W}$. To determine the optimal time for sonication, 5 samples (buffer ST) were divided into $750 \mu \mathrm{l}$ each and sonicated for $10,20,30,40,50$, and 60 seconds. For testing the homogenizing medium, the standardized sonication time was 1 minute per $1 \mathrm{ml}$ homogenate.

\section{Measurement of enzyme kinetics}

The maximal rate of substrate turnover of the selected enzymes was measured in the homogenate at $30^{\circ} \mathrm{C}$. using new or modified assays (s. tab. 1). All catalytic activity concentrations are expressed in $U / 1$, one $U$ corresponding to $1 \mu \mathrm{mol}$ substrate turnover per minute.

Methods were modified with a view to standardizing all the methods as far as possible. Thus, Tris buffer was used, except for the measurement of phosphorylase a (14), retaining the $\mathrm{pH}$ and concentration as described. With the exception of adenylate

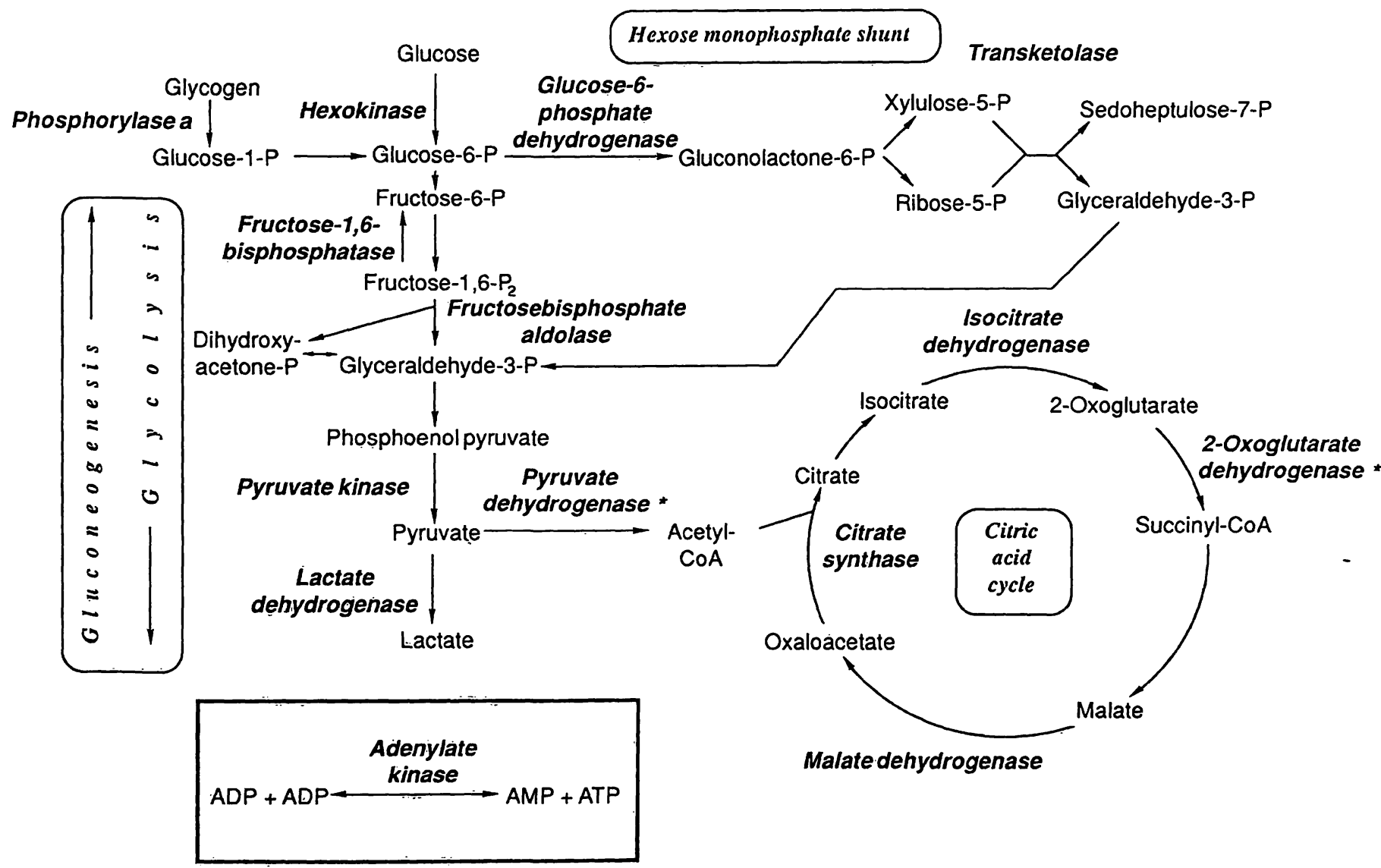

Fig. 1. Localisation of the studied enzymes (*lipoamide dehydrogenase is part of the pyruvate dehydrogenase and oxoglutarate dehydrogenase complex). 


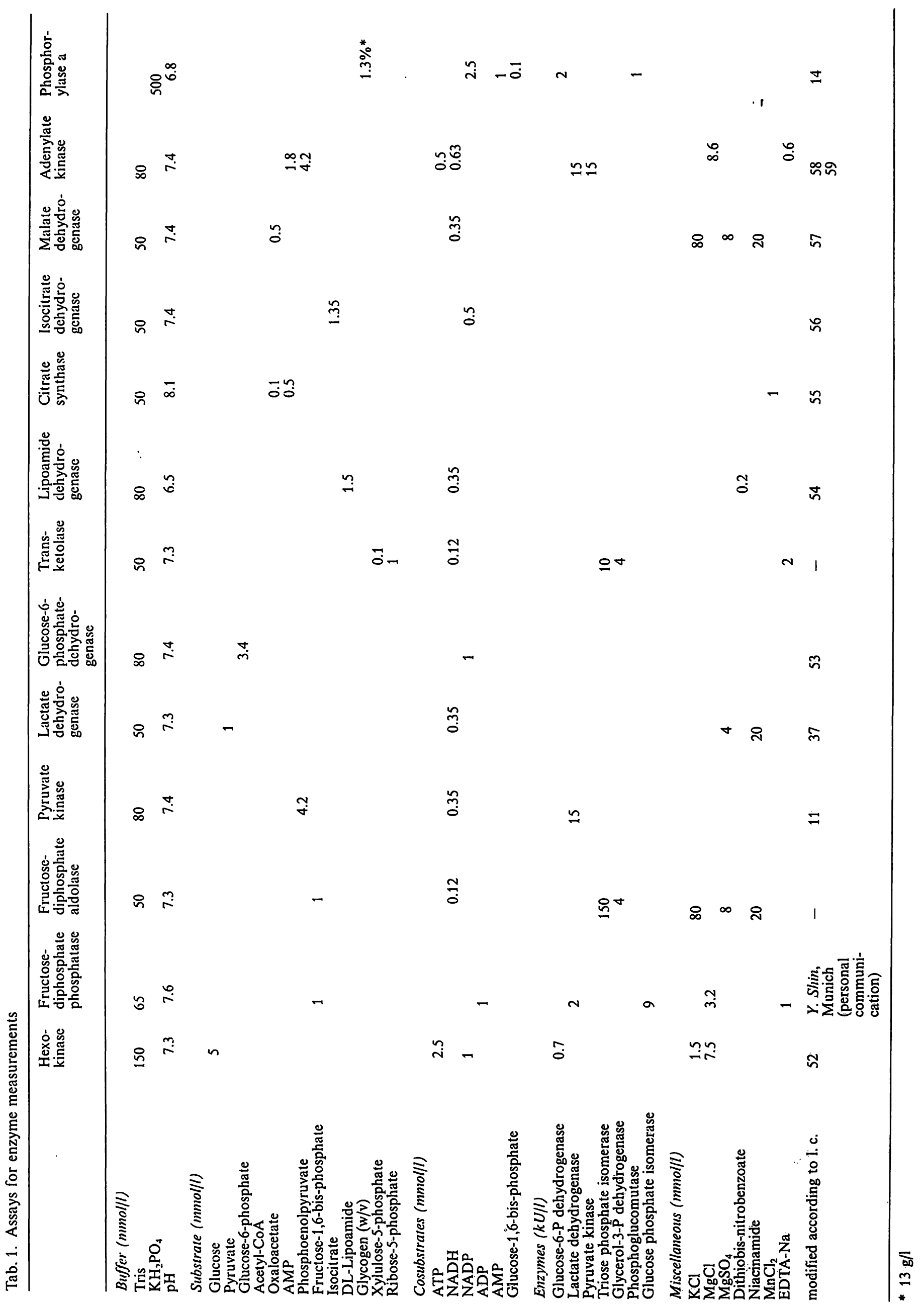

Eur. J. Clin. Chem. Clin. Biochem. / Vol. 31, 1993 / No. 1 
kinase, the NADH concentration was reduced to a maximum of $0.35 \mathrm{mmol} / \mathrm{l}$, to use the range of high signal-to-noise ratio of the photometer. Concentrations of substrates and cosubstrates were increased, attaining linearity for at least 4 minutes (adenylate kinase: AMP $1.8 \mathrm{mmol} / \mathrm{l}$; glucose-6-phosphate dehydrogenase: NADP $1 \mathrm{mmol} / \mathrm{l}$; hexokinase: glucose $5 \mathrm{mmol} / \mathrm{l}$, NADP $1 \mathrm{mmol} / \mathrm{l}$; lipoamide dehydrogenase: lipoamide 1.5 $\mathrm{mmol} / \mathrm{l})$. An optimization of $\mathrm{pH}$ was dispensed with.

\section{Determination of the precision of the method}

The reproducibility of the continuous photometric measurements was determined by 24 measurements of one homogenate using a multi-channel photometer (Biotec EL 340) and microplates (Costar \#3590). For two enzymes, additionally 20 aliquots were taken from the suspension, homogenized separately and measured simultaneously with the homogenate of the remaining suspension. To determine the overall reproducibility of the method, 8 blood samples were taken from one healthy subject at the same time, and these were processed and measured simultaneously (buffer ST).

\section{Storage during the measurement of enzyme activity}

Measurement of 13 enzymes in a small number of samples takes several hours. During this time the homogenates should be kept on ice to avoid loss of activity. In separate runs the selected enzymes were measured repeatedly during 15 hours under constant conditions.

\section{Results}

We found differences in the activities of all enzymes, depending on the buffer used for the homogenization. Table 2 summarizes the mean activities of 12 samples; figure 2 shows the proportional deviation from the activity in buffer ST, when buffer DTT, TX, and DOC was used. Large interindividual differences associated with the presence of the additives are evident. Addition of the detergents, Triton X-100 and deoxycholic acid, and the SH-group protecting dithiothreitol, re-

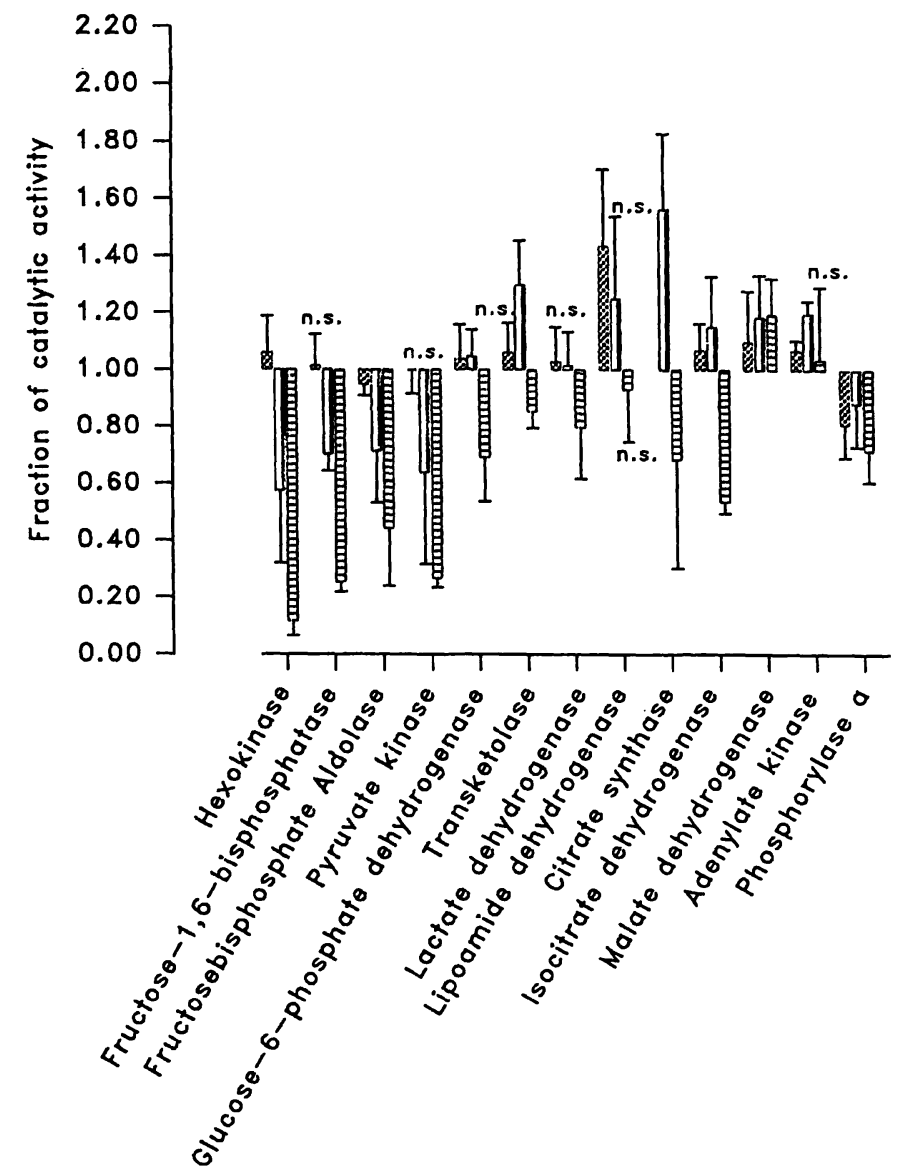

Fig. 2. Fraction of deviation of mean activities, measured in polymorphonuclear leukocyte homogenate containing

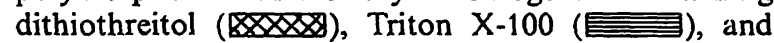
deoxycholate (피피), from those measured using standard buffer $(n=12)$.

n. s.: difference from zero not significant (Wilcoxon)

sulted in an increase of activity only in a minority of the assays. In particular, Triton inhibited most of the studied enzymes.

Tab. 2. Enzyme activities in polymorphonuclear leukocyte homogenate in dependence on the used buffer (ST: standard buffer, DTT: containing dithiothreitol, $2 \mathrm{mmol} / \mathrm{l}$; TX: containing Triton X-100, $1 \mathrm{mmol} / \mathrm{l}$; DOC: containing deoxycholate, $5 \mathrm{mmol} / \mathrm{l}$. All activities in $\mathrm{U} / \mathrm{l}=1 \mu \mathrm{mol} / \mathrm{min} \cdot 1(\mathrm{n}=12)$.

\begin{tabular}{|c|c|c|c|c|c|c|c|c|}
\hline \multirow[t]{2}{*}{ Enzyme } & \multicolumn{2}{|c|}{ Standard } & \multicolumn{2}{|l|}{ DTT } & \multicolumn{2}{|l|}{ DOC } & \multicolumn{2}{|l|}{ TX } \\
\hline & $\overline{\mathbf{x}}$ & s & $\overline{\mathbf{x}}$ & s & $\overline{\mathbf{x}}$ & $\mathbf{s}$ & $\overline{\mathbf{x}}$ & s \\
\hline Hexokinase & 39.6 & 27.3 & 39.9 & 26.9 & 29.6 & 28.1 & 3.9 & 2.9 \\
\hline Gluçose-6-phosphate dehydrogenase & 596.3 & 116.6 & 625.7 & 155.0 & 632.3 & 158.6 & 425.6 & 168.7 \\
\hline Aldolase A & 118.7 & 27.4 & 112.3 & 25.2 & 80.4 & 14.4 & 47.9 & 20.4 \\
\hline Pyruvate kinase & 4124.7 & 549.2 & 4134.2 & 822.0 & 2764.3 & 1696.8 & 1078.2 & 29.2 \\
\hline Fructose-1,6- $\mathrm{P}_{2}$ phosphatase & 0.76 & 0.18 & 0.83 & 0.20 & 0.45 & 0.11 & 0.23 & 0.05 \\
\hline Lactate dehydrogenase & 2981.8 & 893.1 & 3064.6 & 959.6 & 3028.8 & 978.8 & 2481.4 & 1252.8 \\
\hline Isocitrate dehydrogenase & 44.1 & 6.4 & 47.3 & 8.8 & 50.7 & 10.8 & 23.7 & 4.1 \\
\hline Citrate synthase & 32.0 & 5.4 & & & 51.0 & 14.8 & 21.4 & 12.4 \\
\hline Malate dehydrogenase & 482.0 & 62.6 & 526.0 & 88.7 & 565.9 & 67.6 & 573.3 & 72.9 \\
\hline Adenylate kinase & 163.2 & 9.9 & 174.4 & 13.3 & 195.5 & 13.2 & 170.0 & 44.8 \\
\hline Transketolase & 0.99 & 0.27 & 0.89 & 0.24 & 1.22 & 0.33 & 0.89 & 0.24 \\
\hline Phosphorylase a & 9.60 & 2.66 & 8.64 & 2.39 & 8.16 & 2.26 & 8.54 & 2.37 \\
\hline Lipoamide dehydrogenase & 29.7 & 13.8 & 34.3 & 28.2 & 24.8 & 8.9 & 31.2 & 24.9 \\
\hline
\end{tabular}


The duration of exposure to ultrasound had no influence on the activities of hexokinase, adenylate kinase, fructose-di-phosphate aldolase, glucose-6-phosphate dehydrogenase, and malate dehydrogenase. The values for hexokinase suggest a slight, non-significant decrease in activity with increasing sonication time (fig. 3).

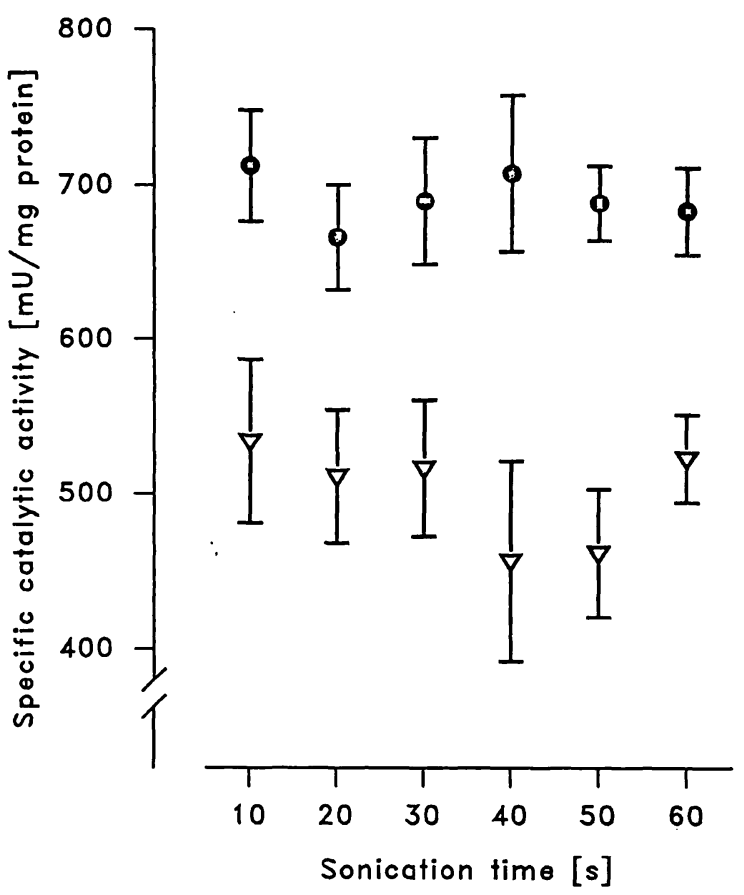

Fig. 3a. Measured activities of glucose-6-phosphate dehydrogenase $(\bullet)$ and malate dehydrogenase $(\nabla)$, in polymorphonuclcar leukocyte homogenate, in dependence on the duration of sonication $(750 \mu$ l polymorphonuclear leukocyte suspension; $n=8$ ).
Figure 4 traces the activities of glucose-6-phosphate dehydrogenase, isocitrate dehydrogenase, fructose-diphosphate aldolase, and adenylate kinase in dependence on the time of storage at $2^{\circ} \mathrm{C}$. For these, as well as for all other studied enzymes, we did not find a significant increase or decrease over a time of 15 hours.

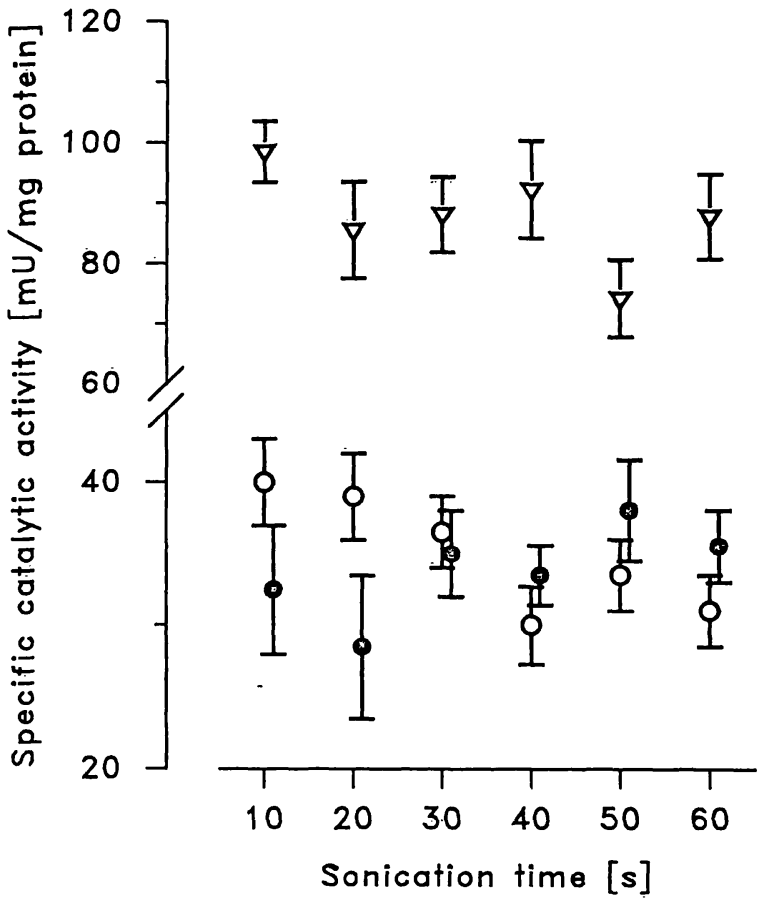

Fig. 3b. Measured activities of hexokinase (o), adenylate kinase $(\bullet)$ and aldolase $(\nabla)$ in polymorphonuclear leukocyte homogenate, in dependence on the duration of sonication $(750 \mu \mathrm{l}$ polymorphonuclear leukocyte suspension; $\mathrm{n}=8$ ).

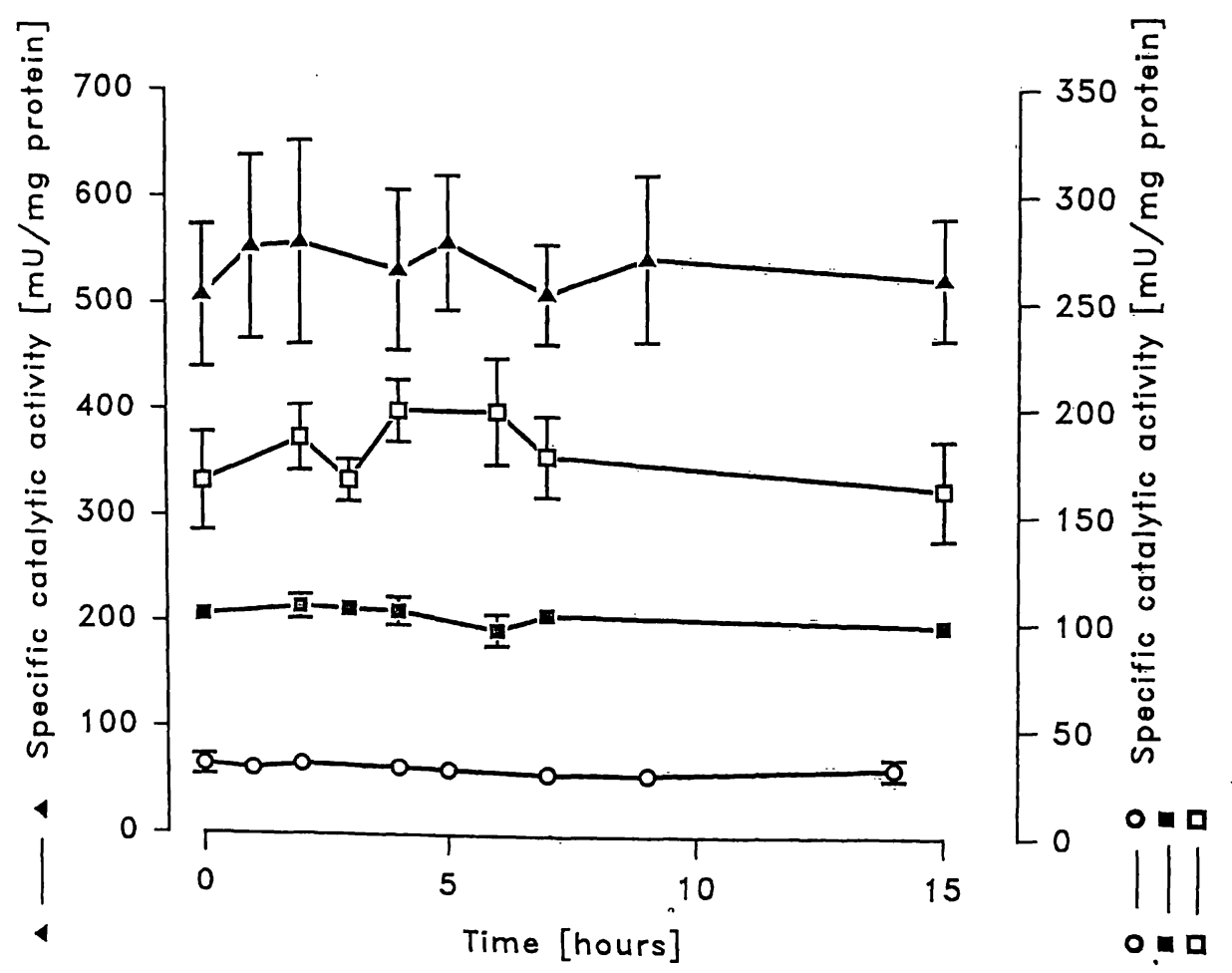

Fig. 4. Activity of glucose-6-phosphate dehydrogenase $(\nabla)$, isocitrate dehydrogenase ( 0 ), aldolase ( $\square$ ) änd adenylate kinase ( $\square$ ) in polymorphonuclear leukocyte homogenate, in dependence on the duration of storage at $2^{\circ} \mathrm{C}(\mathrm{n}=10)$. 
Tab. 3. Mean activity of enzymes and precision of a 24-fold measurement from one polymorphonuclear leukocyte homogenate $(\mathrm{mU} / \mathrm{mg}$ protein; $1: 3,1: 6=$ homogenate diluted).

\begin{tabular}{lrr}
\hline Enzyme & $\overline{\mathrm{x}}$ & \multicolumn{1}{c}{ CV } \\
& & $(\%)$ \\
\hline Hexokinase & 35.6 & 8.0 \\
Glucose-6-phosphate dehydrogenase & 360.7 & 5.3 \\
Aldolase A & 66.3 & 4.7 \\
Pyruvate kinase & 670.5 & 4.7 \\
Fructose-1,6-P ${ }_{2}$ phosphatase & 0.7 & 10.1 \\
Lactate dehydrogenase $(1: 6)$ & 2180.0 & 6.4 \\
Lactate dehydrogenase $(1: 3)$ & 1925.8 & 5.5 \\
Isocitrate dehydrogenase & 297.3 & 4.7 \\
Citrate synthase & 67.3 & 4.5 \\
Malate dehydrogenase & 372.7 & 7.1 \\
Adenylate kinase & 87.3 & 9.3 \\
Transketolase & 0.7 & 14.4 \\
Phosphorylase a & 8.5 & 11.4 \\
Lipoamide dehydrogenase & 46.5 & 9.6 \\
\hline
\end{tabular}

The precision of the photometric activity measurement, expressed as the coefficient of variation (CV), was below $15 \%$ for all enzymes, and below $10 \%$ when fructose-1,6-diphosphatase, phosphorylase $a$ and transketolase are excluded (tab. 3). It is higher with decreasing absolute activity of the enzyme (fig. 5).

Precision is considerably lower when a sample is divided into parts before sonication. Under these conditions ('aliquotation'), the CV was $25.5 \%$ and $16.5 \%$

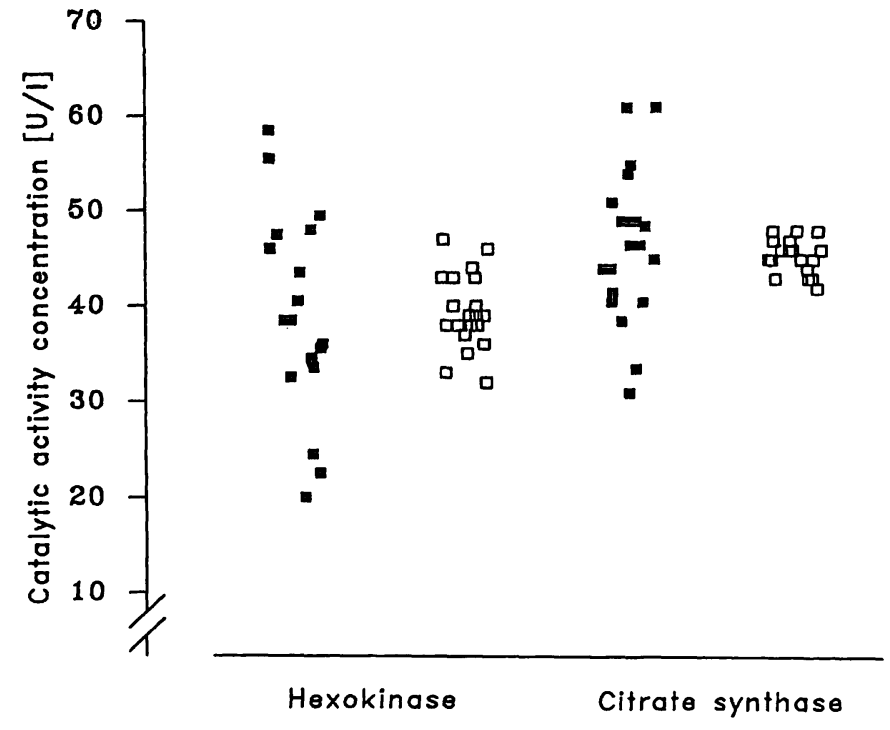

Fig. 6. Precision of multiple measurements of hexokinase and glucose-6-phosphate dehydrogenase in one homogenate $(\square)$, and a suspension (a) which was split before homogenization $(x \pm s ; n=20)$.

for hexokinase and citrate synthase, respectively, compared with $9.9 \%$ and $3.9 \%$ when determined by multiple analysis of one homogenate (fig. 6).

As expected, the precision of enzyme activities related to the protein content was considerably lower $(\mathrm{CV}$ $8.3-15.4 \%$ ) when enzyme activities were determined in separately prepared samples of polymorphonuclear leukocytes from one patient (tab. 4).

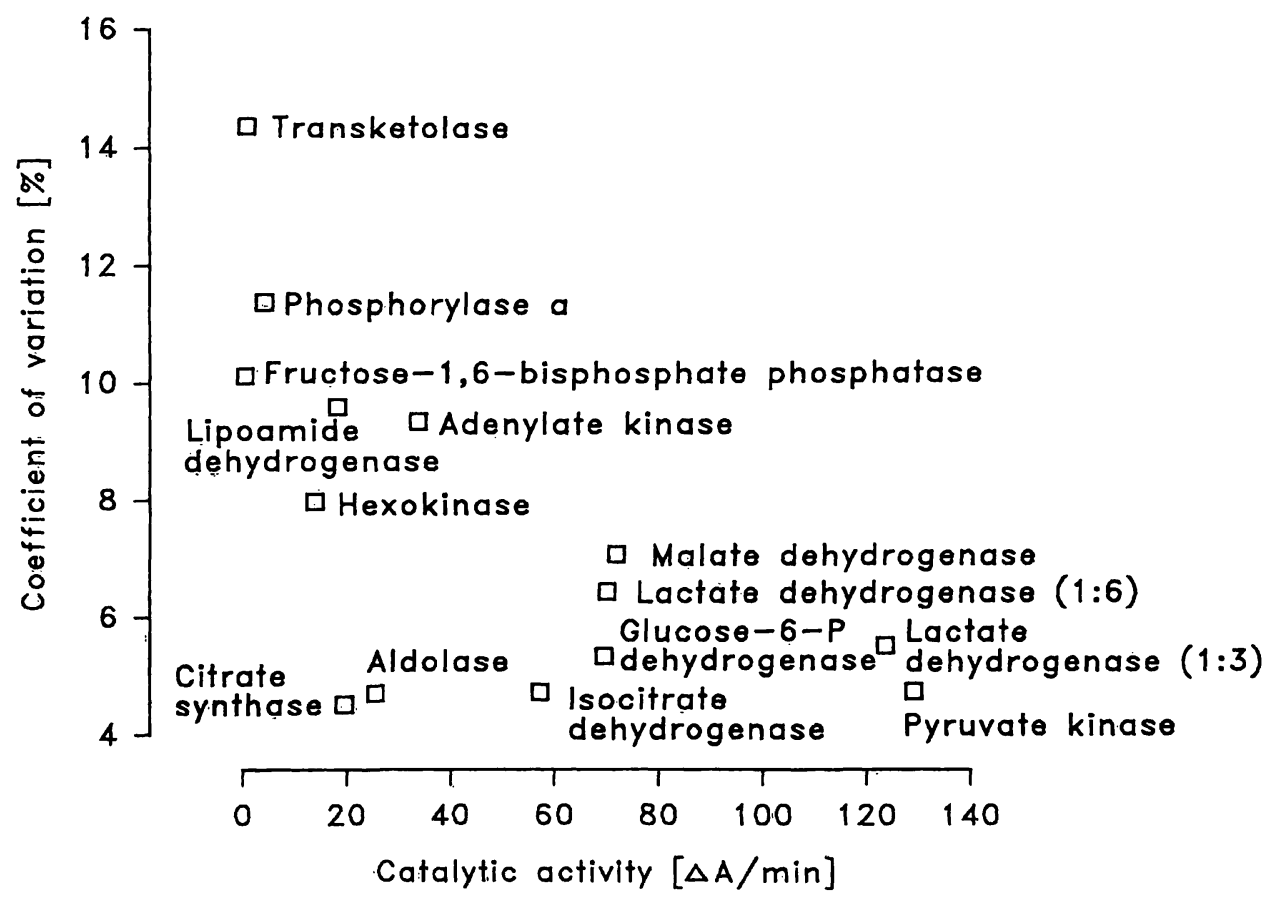

Fig. 5. Correlation between precision and measured activity $(\Delta \mathrm{A} / \mathrm{min}$ : change of absorbance in the assay per minute; for lactate dehydrogenase measurement homogenate was diluted $1: 3,1: 6$. 
Tab. 4. Activity and precision of enzymes in polymorphonuclear leukocyte suspensions, processed separately from 8 simultaneously drawn blood samples of one subject (mU/mg protein).

\begin{tabular}{lrrr}
\hline Enzyme & $\overline{\mathrm{x}}$ & $\mathrm{s}$ & \multicolumn{1}{c}{ CV } \\
& & & $(\%)$ \\
\hline Hexokinase & 42.3 & 5.2 & 12.3 \\
Glucose-6-phosphate dehydrogenase & 416.1 & 44.7 & 10.7 \\
Aldolase A & 65.4 & 5.4 & 8.3 \\
Pyruvate kinase & 904.3 & 103.7 & 11.5 \\
Fructose-1,6-P 2 phosphatase & 0.97 & 0.13 & 13.4 \\
Lactate dehydrogenase & 2231.0 & 243.5 & 10.9 \\
Isocitrate dehydrogenase & 45.0 & 5.3 & 11.8 \\
Citrate synthase & 21.1 & 1.8 & 8.5 \\
Malate dehydrogenase & 395.4 & 46.0 & 11.6 \\
Adenylate kinase & 106.2 & 14.9 & 14.0 \\
Transketolase & 1.3 & 0.2 & 15.4 \\
Phosphorylase a & 11.3 & 1.7 & 15.0 \\
Lipoamide dehydrogenase & 12.8 & 1.6 & 12.5 \\
\hline
\end{tabular}

\section{Discussion}

\section{Selection of enzymes}

Enzymes were selected to represent all the stages of carbohydrate metabolism, including complete oxidation in the citric cycle. For this purpose, enzymes were chosen, which are considered to be rate limiting for the corresponding metabolic pathway (so-called fluxgenerating steps (15)), or which are situated at a prominent place in the flux of metabolites (fig. 1).

Hexokinase and glucose-6-phosphate dehydrogenase are considered to be flux generating for glycolysis and the hexose monophosphate shunt $(16-20)$. Glucose6-phosphate dehydrogenase in particular plays an important role in the polymorphonuclear leukocyte, for the metabolic burst, connected with chemotaxis and phagocytosis, is primarily supplied by this pathway.

In the polymorphonuclear leukocyte glucose metabolism is predominantly anaerobic, and proceeds to lactate (16). Lactate dehydrogenase is important in all tissues for the recirculation of pyruvate to hepatic gluconeogenesis within the Cori cycle. Beck found a linear correlation between lactate dehydrogenase activity and the rate of glycolysis of the intact cell in both normal and leukaemic leukocytes (2).

Although activity is high, pyruvate kinase correlates closely to the lactate production of the polymorphonuclear leukocytes (21) and is assumed to be rate limiting for glycolysis, too (19).

Fructose di-phosphate aldolase was selected due to its position between the metabolism of the hexoseand triose phosphates in glycolysis, citrate synthase because of its key position between the anerobic part of glycolysis and the citric cycle. Isocitrate dehydro- genase and malate dehydrogenase represent oxidizing steps in the citric acid cycle.

By regulating the intracellular energy level by the synthesis of ATP from low energy nucleotides, the enzyme adenylate kinase plays an essential role in the energy homoiostasis of the cell. Deviations in the activity of this enzyme are interpretated as a sign of a disturbed cellular energy metabolism (22).

Not only enzymes with low in vitro activities are suitable for the evaluation of substrate fluxes in vivo. By appropriate subcellular localization, the presence of membrane boundaries, local differences of concentrations of substrate and cofactors, and allosteric regulation, even enzymes with high maximal flux rates of substrate can catalyse a rate limiting step $(23,24)$.

\section{Homogenization}

According to Andersen et al. (25), a suitable technique for homogenization as well as the determination of reference substance concentration contributes more to the technical limitation of enzyme measurements than the photometric assay itself. An optimal homogenization of a tissue should guarantee a maximal liberation of enzyme protein, together with a reliable preservation of the catalytic activity.

Polymorphonuclear leukocytes are commonly disintegrated manually in glass homogenizers (Potter-Elvehjem) $(26,27)$. However, Beutler (28) reported that this method produced insufficient disintegration, and it was necessary to supplement the procedure with the single- or several-fold freezing and thawing of leukocyte suspensions. Read (27) combined glass homogenization with a subsequent sonication. Other authors use the cryotechnique exclusively.

The procedure of cryohomogenization can be used for blood cells as well as subcellular structures. It is based upon the formation of intracellular ice crystals, which can be demonstrated by light and electron microscopy (29). Usually, two or three $(3,4)$, sometimes four cycles (20) of freezing and thawing are described, sometimes followed by an additional homogenization in the Potter-Elvehjem (11) homogenizer.

Systematic and, above all, comparative studies of different homogenizing techniques are not found in the literature. Bertino (26) found no differences between the activities of glucose-6-phosphate dehydrogenase in leukocytes homogenized by three-fold freezing/thawing, and those prepared by homogenization in a Potter-Elvehjem homogeniżér. In contrast, neuraminidase of polymorphonuclear leukocytes suffers a 
loss of activity of $50 \%$ after four-fold freezing/thawing, compared with in vitro measurements on intact cells (30).

In our studies we found insufficient cell destruction after thawing of cryopreserved polymorphonuclear leukocyte suspensions. Subsequent complete homogenization by ultrasound yielded an homogenate, which exhibited lower activities of most of the enzymes, compared with sonication before freezing the sample. Also the reproducibility of the enzyme kinetics was markedly worse. We interpret this as an inactivation of enzymes by a high intracellular concentration of lysosomal enzymes from destroyed lysosomes, while the outer cell membrane is still preserved. In comparison, sonication guarantees an immediate dilution of all enzymes by a rapid and complete destruction of all structures.

Homogenization of polymorphonuclear leukocytes by sonication has been frequently used in recent years (31), but a systematic investigation of the optimal sonication time for leukocytes has not hitherto been reported. Our results demonstrate that the duration of sonication, given an appropriate cooling of the sample, is not critical. A sonication power of 50 watt, and developing times between 10 and 60 seconds per $750 \mu$ l suspension resulted in constant activities for all enzymes (fig. 3). This is attributed to a structurestabilizing effect of the relatively high viscosity of the homogenizing medium on the enzyme proteins.

\section{Homogenizing medium}

The variety of proposed media for the homogenization of leukocytes and other tissues is immense. It extends from water without any additions (32) over diverse ionic and anionic buffers to complex compounds and highly viscous buffers. Especially glycerol-containing buffers are frequently used $(27,33)$.

Various additives are supposed to increase the proportion of dissolved membrane-bound enzymes and to protect dissolved enzymes against loss of activity during homogenization, storage and measurement. In particular, detergents and SH-group protecting agents are frequently used.

Dithiothreitol was introduced by Cleland (34) as a reagent to protect $\mathrm{SH}$-groups from oxidation to disulphide bonds. It is used for the homogenization of leukocytes (35) and other tissues $(36,37)$, and is often also added to the continuous photometric assay. The broad range of the concentrations in use (data between $0.1 \mathrm{mmol} / \mathrm{l}(36)$ and $10 \mathrm{mmol} / \mathrm{l}(35)$ are reported in the literature) suggests that these are chosen rather arbitrarily.
Of the studied enzymes, a significantly positive effect of dithiothreitol (more than $10 \%$ increase of activity) on the measured activities could only be demonstrated for lipoamide dehydrogenase (see fig. 2). Citrate synthase can only be measured in a dithiothreitol-free medium due to the disulphide group of 5,5'-dithiobis(2-nitrobenzoic acid) (Ellman's reagent (38)) in the assay. The use of dithiothreitol requires a splitting of the polymorphonuclear leukocyte suspension before homogenization.

Some of the selected enzymes are membrane-bound (malate dehydrogenase, citrate synthase, isocitrate dehydrogenase partially). Detergents reduce the surface tension of membranes and can increase the solubility of membrane-bound enzymes in hydrous solutions $(39,40)$, resulting in a higher yield of activity.

Beyond a critical concentration ('critical micellation concentration', CMC) detergents tend to form micelles with membrane fragments and possibly integrated enzyme proteins (41). This micellation is responsible for the better solubility of the enzymes, but can also prevent detection, when enzyme protein is captured in the micelle or located at the inner surface of the membrane.

We studied one ionic (deoxycholate, $\mathrm{CMC}=1-2$ $\mathrm{mmol} / \mathrm{l}$ ) as well as one non-ionic detergent (Triton $\mathrm{X}$ $100, \mathrm{CMC}=0.29 \mathrm{mmol} / 1(63,67))$.

The tested concentrations in the homogenate were significantly above the $\mathrm{CMC}$ of the substance $(5 \mathrm{mmol} / \mathrm{l}$ deoxycholate and $1 \mathrm{mmol} / \mathrm{l}$ Triton X-100, respectively). In the assay the homogenate is diluted between 10 - and 40 -fold, so that the detergent concentration falls below its $\mathrm{CMC}$, guaranteeing the liberation of the enzymes from the micelles.

Triton is the most frequently cited detergent for homogenization of tissues or measurements of enzyme activities in biological samples. Concentration data range around $1.5 \mathrm{mmol} / \mathrm{l}$ for the homogenization of leukocytes $(42,43)$, and $0.75 \mathrm{mmol} / \mathrm{l}$ in the assay for the determination of glycolytic enzymes in lymphocytes (35). In fact, a positive effect on the detectable activity is only reported by Stossel et al. (43) for acid phosphatase in phagocytic vesicles of the polymorphonuclear leukocytes, while neuraminidase activity in the human leukocyte is decreased to $40 \%$ by Triton concentrations between 0.75 and $6.1 \mathrm{mmol} / \mathrm{l}(30)$.

The use of deoxycholate as an additive to the homogenizing medium for leukocytes is reported for example by Yeh et al. (30), with concentrations ranging between 2.4 and 9.6. Information about the influence of deoxycholate on the detectable activity is only 
given by Ych, who reported that the neuraminidase in leukocyte homogenates was reduced by about $20 \%$.

High concentrations of deoxycholic acid can inactivate a number of membrane-bound enzymes (44). Coupling of the detergent to the active site of the enzyme is conceivable (39) as well as destruction of the tertiary and quaternary structure of the molecule (45).

In this study, the measured activities differed from those of the same suspension, homogenized without detergent, in an unpredictable manner. In all, a negative effect predominated, and in particular we observed no increase in the activity of membrane bound enzymes. Deoxycholate resulted in a significant inhibition of nearly all enzymes.

In view of these results, it is doubtful whether the addition of the detergents cited above has a positive effect on the measured enzyme activities of polymorphonuclear leukocytes.

\section{Sample splitting}

In view of the improvement of activity achieved by homogenization of polymorphonuclear leukocytes (in the case of certain enzymes in the presence of dithiothreitol or detergents) investigators may be led to split the cell suspension and to process the separate parts using different homogenizing media. This involves considerable extra work, and assumes that the aliquotation of the sample does not affect the precision of measurement.

The effect of splitting the polymorphonuclear leukocyte suspension was studied for the measurement of hexokinase and citrate synthase; the resulting imprecision was unacceptably high, compared with a multiple determination from one homogenate (s. fig. 6).

However, the sample must be split for the determination of reference substance concentrations, which cannot be measured directly in the final homogenate (e. g. protein and DNA).

Consequently, splitting of the polymorphonuclear leukocyte suspension before homogenization, followed by the use of different buffers for achieving maximal enzyme activities, cannot be recommended. Splitting for the determination of reference values is possible with a smaller error, and in any case cannot be avioided.

\section{Thermal stability}

Storage of enzyme-containing samples in liquid nitrogen for months does not result in a loss of activity (46), provided the time of thawing is sufficiently short
( $>20^{\circ} \mathrm{C} /$ minute (47)). In contrast, storage on ice between thawing and measurement of the enzyme can possibly lead to a loss of enzyme activity. In our laboratory, storage times of up to 15 hours are usual. Our study showed that enzyme activities remain stable over a period of 15 hours after thawing. This agrees with results of Shonk (48) and Gantner (49) for liver and muscle homogenate.

\section{Precision of continuous photometric assays}

The precision of an analytical procedure can be determined from consecutive measurements of one sample. In general, the coefficient of variation as a measure of precision is slightly higher for manually performed continuous measurements than for end point assays.

In the clinical area, $\mathrm{CV}$ values below $10 \%$ are given as state-of-the-art for enzyme measurements (50). Very few authors quote precisions for the measurement of enzyme activities in tissue homogenates. Miva (3) specifies CV values for pyruvate kinase $(12.4 \%)$, 3-phosphoglycerate kinase $(4.4 \%)$, enolase (3.6\%), and 2,3-phosphoglycerate mutase (5.5\%) for leukocyte homogenate. In polymorphonuclear leukocyte homogenate, Distler (12) determined CV's between $11 \%$ and $21.2 \%$ for the enzymes pyruvate kinase, adenylate kinase, phosphofructokinase, and glucose-6-phosphate dehydrogenase $(\mathrm{n}=10)$.

In our measurements the precision for the studied enzymes ranged between $4.5 \%$ (citrate synthase) and $14.4 \%$ (transketolase), with the well known inverse relation between absolute change of absorbance per time and CV (fig. 5).

\section{Precision of the overall method}

The CV values for the enzyme activity per mg protein from several blood samples of one subject is about 20 to $100 \%$ higher than the CV value for the continuous photometric measurement alone (see tabs. 3 and 4) This means that the overall contribution of separation, homogenization, and protein analysis, including the necessary splitting of the suspension, is equal to or less than the inaccuracy of the continuous measurement alone. Thus, an optimization of the continuous photometric measurement, i.e. maximization of the measurable activity of the enzymes, is the critical factor for further improvement of the overall method.

Table 5 indicates the range and interindividual scattering of the enzyme activities in healthy subjects after an overnight fast, determined by the described method. 
Tab. 5. Activity of the studied enzymes in polymorphonuclear leukocyte homogenate of healthy subjects (age $35 \pm 16$ years) after an overnight fast.

\begin{tabular}{llcc}
\hline Enzyme & $\mathrm{n}$ & $\overline{\mathbf{x}}$ & $\mathrm{s}$ \\
\hline Hexokinase & 24 & 66 & 24 \\
Glucose-6-P dehydrogenase & 21 & 71 & 25 \\
Aldolase A & 24 & 36 & 11 \\
Pyruvate kinase & 24 & 858 & 247 \\
Fructose-1,6- $\mathrm{P}_{2}$ phosphatase & 18 & 0.94 & 0.41 \\
Lactate dehydrogenase & 23 & 2964 & 632 \\
Isocitrate dehydrogenase & 24 & 59 & 17 \\
Citrate synthase & 22 & 39 & 12 \\
Malate dehydrogenase & 24 & 655 & 248 \\
Adenylate kinase & 24 & 143 & 98 \\
Transketolase & 16 & 0.89 & 0.18 \\
Phosphorylase a & 14 & 13.4 & 3.1 \\
Lipoamide dehydrogenase & 23 & 23 & 8 \\
\hline
\end{tabular}

\section{Conclusion}

For several reasons, the polymorphonuclear leukocyte is a suitable model for metabolic studies. It is easy to obtain without strain on the subject; in contrast to erythrocytes, it contains all the enzymes of energy metabolism; the influence of insulin on the metabolism of separated polymorphonuclear leukocytes indicates that alterations in the metabolism of polymorphonuclear leukocytes gives at least limited information about the metabolism of the entire organism $(18,51)$.

\section{References}

1. Böyum, A. (1967) Isolation of leukocytes from human blood. Scand. J. Clin. Lab. Invest. (Suppl. 97) 21, 9-29.

2. Beck, W. S. (1955) A kinetic analysis of the glycolytic rate and certain glycolytic enzymes in normal and leukemic leucocytes. J. Biol. Chem. 216, 333-350.

3. Miwa, S., Tanaka, K. \& Valentine, W. (1962) Erythrocytic and leukocyte glycolytic enzyme studies in hematologic and nonhematologic diseases. Acta Haematol. Jap. 25, 12-26.

4. Ramot, B., Fischer, S., Szeinberg, A., Adam, A., Sheba, C. \& Gafni, D. (1959) A study of subjects with erythrocyte glucose-6-phosphate dehydrogenase deficiency. II. Investigation of leukocyte enzymes. J. Clin. Invest. 38, 22342237.

5. Vetter, K. (1961) Über das Verhalten vọ Fermenten in normalen und pathologischen menschlichen Leukozyten. Acta Haematol. 26, 344-355.

6. Klebanoff, S. J. \& Clark, R. A. (1978) The Neutrophil Function and Clinical Disorders. Amsterdam, North Holland.

7. Cartwright, G. E., Athens, W. \& Wintrobe, M. M. (1964) The kinetics of granulopoiesis in normal man. Blood 24, $780-803$.

8. Fauth, U., Heinrichs, W., Puente-Gonzalez, I. \& Halmágyi, M. (1990) Maximale Umsatzraten an Enzymen der Glykolyse und des Zitratzyklus von separierten Granulozyten in der postoperativen Phase. Infusionstherapie 17, 178183.

9. Metcoff, J., Lindemann, R., Baxter, D. \& Pederson, J. (1978) Cell metabolism in uremia. Am. J. Clin. Nutr. 30, $1627-1634$.
The presented method gives reproducible results for the maximal in vitro rates of substrate turnover of several important enzymes of carbohydrate and energy metabolism of the polymorphonuclear leukocytes.

The continuous photometric determination of enzyme activities can be identified as the main factor affecting the precision of the overall method. However, the activity yields of the enzymes of interest can be optimized only by separate processing of the cell suspension in different homogenizing media. This requires a splitting of the suspension, which leads to considerable inaccuracy, even when mixing is observed thoroughly, and thus should be limited to the inevitable taking of samples for protein or DNA analysis.

The most suitable technique for the homogenization of polymorphonuclear leukocyte suspensions is sonication by ultrasound. When adequate cooling of the sample is observed, the duration of sonication is not critical.

In summary, by paying attention to the described practical aspects of sample processing, enzymes can be measured in the polymorphonuclear leukocyte with a precision that meets the requirements of clinical laboratory tests. The model is therefore sufficiently sensitive for biochemical or clinical trials.

10. Metcoff, J., Fürst, P., Scharer, K., Distler, G., Weber, R., Mangold, J., Graser, T., Pfaff, G. \& Schonberg, D. (1989) Energy production, intracellular amino acid pools, and protein synthesis in chronic renal disease. J. Am. Coll. Nutr. $8,271-284$.

11. Mameesh, M. S., Metcoff, J., Costiloe, P. \& Crosby, W. (1976) Kinetic properties of pyruvate kinase in human maternal leukocytes in malnutrition. Pediatr. Res. 10, $561-$ 565.

12. Distler, G. (1986) Intrazellulärer Stoffwechsel ruhender polymorphkerniger Leukozyten. Isolation, DNA-Bestimmung, Enzyme des Kohlenhydratstoffwechsels, Proteinsyntheserate und freie Aminosäuren, Diplomarbeit, StuttgartHohenheim.

13. Lowry, O. H., Rosebrough, N. J., Farr, A. L. \& Randall, R. J. (1951) Protein measurement with the Folin phenol reagent. J. Biol. Chem. 193, 265-275.

14. Sigma, Chemical Comp., Enzymatic assay of phosphorylase-a.

15. Newsholme, E. A. \& Crabtree, B. (1979) Theoretical principles in the approaches to control of metabolic pathways and their application to glycolysis in muscle. J. Mol. Cell. Cardiol. 11, 839-856.

16. Beck, W. S. (1958) The control of leucocyte glycolysis. J. Biol. Chem. 232, 251-270.

17. Stjernholm, R. L. (1968) The metabolism of leukocytes. Congr. Int. Soc. Hematol. Twelfth N. Y. Plenary Session 5, 175.

18. Esman, V. (1972) The diabetic leukocyte. Enzyme 13, $32-55$. 
19. Minakami, S. (1968) Studies on leucocyte metabolism. I. Glycolytic intermediates and nucleotides in guinea pig exudate granulocytes. J. Biochem. 63, 83-86.

20. Ghiotto, G. N., Perona, G., De, S. \& Cortesi, S. (1963) Hexokinase and TPN-dependent dehydrogenases of leukocytes in leukaemia and other haematological disorders. Br. J. Haematol. 9, 345-350.

21. Das, M., Klein, W. \& Feig, S. (1977) Glycolytic metabolism of neonatal mononuclear cells. Pediat. Res. 11, 1068-1072.

22. Metcoff, J., Wikman-, J., Cofelt, T., Yoshida, A. \& Bernal, A. (1973) Energy metabolism and protein synthesis in human leukocytes during pregnancy and in placenta related to fetal growth. Pediatrics 51,866-877.

23. Eden, E., Bennegard, K., Bylund-F., A., Shersten, T. \& Lundholm, K. (1983) Whole-body energy metabolism and metabolic capacity of skeletal muscles in malnourished patients before and after total parenteral nutrition. Hum. Nutr. Clin. Nutr. 37, 185-196.

24. Niemeyer, H. \& Cardenas, M. (1985) Concurrence of multiple and integrated mechanisms in the modulation of enzyme activities: significance for the regulation of metabolic fluxes. Arch. Biol. Med. Exp. 18, 331-358.

25. Andersen, K. J., Schjonsby, H. \& Skagen, D. W. (1983) Enzyme activities in human and rat jejunal mucosa. Scand. J. Gastroenterol. 18, 241-249.

26. Bertino, J.: R., Silber, M., Freeman, M., Alenty, A., Albrecht, M., Gabrio, B. W. \& Huennekens, F. M. (1963) Studies on normal and leukemic leukocytes. IV. Tetrahydrofolate-dependent enzyme systems and dihydrofolic reductase. J. Clin. Invest. 42, 1899-1907.

27. Read, G., Crabtree, B. \& Smith, G. (1977) The activities of 2-oxoglutarate dehydrogenase and pyruvate dehydrogenase in hearts and mammary glands from ruminants and non-ruminants. Biochem. J. 164, 349-355.

28. Beutler, E. Y. \& Yeh, M. (1959) Aconitase in human blood. J. Lab. Clin. Med. 54, 456-460.

29. Pegg, D. E. (1976) Long-term preservation of cells and tissues: a review. J. Clin. Pathol. 29, 271-285.

30. Yeh, A. K. P., Tulsiani, D. R. \& Carubelli, R. (1971) Neuraminidase activity in human leukocytes. J. Lab. Clin. Med. 78, 771-778.

31. Ryder, E., Campos, G. \& Morales-Villalobos, L. M. (1987) Enzymatic changes in polymorphonuclear cells isolated from type II diabetics. Biochem. Med. Metab. Biol. 37, $205-212$.

32. Dahlquist, A. (1968) Assay of intestinal disaccharidases. Anal. Biochem. 22, 99-107.

33. Alp, P. R., Newsholme, E. A. \& Zammit, V. A. (1976) Activities of citrate synthase and NAD-linked and NADPlinked isocitrate dehydrogenase in muscle from vertebrates and intervertebrates. Biochem. J. 154, 689-700.

34. Cleland, W. W. (1964) Dithiothreitol, a new protective reagent for SH groups. Biochemistry 3, 480-482.

35. Ardawi, M. S. M. \& Newsholme, E. A. (1982) Maximum activities of some enzymes of glycolysis, the tricarboxylic cycle and ketone-body and glutamine utilization pathways in lymphocytes of the rat. Biochem. J. 208, 743-748.

36. Balinsky, D., Cayanis, E., Geddes, E. \& Bersohn, I. (1973) Activities and isoenzyme patterns of some enzymes of glucose metabolism in human primary malignant hepatoma. Cancer Res. 33, 249-255.

37. Silberberg, R., Stamp, W., Lesker, P. \& Hasler, M. (1970) Aging changes in ultrastructure and enzymatic activity of cartilage of guinea pigs. J. Gerontol. 25, 184-198.

38. Ellman, G. P. (1959) Tissue sulfhydryl groups. Arch. Biochem. Biophys. 82, 70-77.

39. Hjelmeland, L. M. (1984) Solubilization of functional membrane proteins. Methods Enzymol. 104, 305-318.
40. Helenius, A., McCaslin, D., Fries, E. \& Tanford, C. (1979) Properties of detergents. Methods Enzymol. 56, 734-749.

41. Tanford, C. \& Reynolds, J. (1976) Caracterization of membrane proteins in detergent solution. Biochim. Biophys. Acta 457, 133-170.

42. Tanaka, T. (1978) I-cell disease: effects of infection and prednisolone on lysosomal enzymes in leukocytes and blood plasma. Hiroshima J. Med. Sci. 27, 193-202.

43. Stossel, T. P., Pollard, T. D. \& Mason, R. J. (1971) Isolation and properties of phagocytic vesicles from polymorphonuclear leucocytes. J. Clin. Invest. 50, 1745-1757.

44. Helenius, A. \& Simons, K. (1975) Solubilization of membranes by detergents. Biochim. Biophys. Acta 415, 29-79.

45. Liscia, D. S., Alhadi, T. \& Vonderhaar, B. K. (1982) Solubilization of active prolactin receptors by a nondenaturating zwitterionic detergent. J. Biol. Chem. 257, $9401-$ 9405.

46. Jung, K., Bader, K. \& Grützmann, K. (1984) Long-term stability of enzymes in human serum stored in liquid nitrogen. Enzyme 31, 209-216.

47. Fishbein, W. N. \& Winkert, J. W. (1979) Parameters of freezing damage to enzymes. In: Proteins at Low Temperatures (Fennema, O., ed.) pp. 55-82. Adv. Chem. Series 180, American Chemical Society, Washington.

48. Shonk, C. E. \& Boxer, G. E. (1964) Enzyme patterns in human tissues. 1. Methods for the determination of glycolytic enzymes. Cancer Res. 24, 709-721.

49. Gantner, G. \& Hamm, R. (1964) Transaminasen des Fleisches. Extrahierbarkeit und Eigenschaften von Transaminasen (GOT und GPT) aus Schweinemuskel. Z. Lebensmitt. Unters. Forsch. 126, 1-10.

50. Lohff, M. R., DiSilvio, T. V., Ross, J. W., Lawson, N. S. \& Gilmore, B. F. (1982) Analytic clinical laboratory precision. State of the art for selected enzymes. Am. J. Clin. Pathol. (Suppl.) 78, 634-643.

51. Martin, S. P., McKinney, G. R., Green, R. \& Becker, C. (1953) The influence of glucose, fructose, and insulin on the metabolism of leucocytes of healthy and diabetic subjects. J. Clin. Invest. 32, 1171-1174.

52. King, R. F. G., Macfie, J. \& Hill, G. (1981) Activities of hexokinase, phosphofructokinase, fructose biphosphatase and 2-oxoglutarate dehydrogenase in muscle of normal subjects and very ill surgical patients. Clin. Sci. $60,451-$ 456.

53. Kornberg, A. \& Horecker, B. (1955) Glucose-6-phosphate dehydrogenase. In: Methods in Enzymology (Colowick, S. P. \& Kaplan, N. O., eds.) 1, p. 323, Academic Press, New York.

54. Gottesmann, P. \& Hamm, R. (1984) Lipoamiddehydrogenase, Citratsynthase und $\beta$-Hydroxyacetyl-CoA-Dehydrogenase des Skelettmuskels. $Z$. Lebensm. Unters. Forsch. $178,366-370$.

55. Srere, P. A., Brazil, H. \& Gonen, L. (1963) The citrate condensing enzyme of pigeon breast muscle and moth flight muscle. Acta Chem. Scand. (Suppl.) 17, S129-S134.

56. Swierczynski, J., Aleksandrowicz, Z. \& Zelewski, L. (1986) Carboxylation of pyruvate via extramitochondrial malic enzyme in rat skeletal muscle. Acta Biochim. Pol. 33, $47-54$.

57. Ochoa, S. (1955) Malic dehydrogenase from pig heart. In: Methods in Enzymology (Colowick, S. P. \& Kaplan, N. O., eds.) 1,735 , Academic Press, London, New York.

58. Rhoads, D. G. \& Lowenstein, J. M. (1968) Initial velocity and equilibrium kinetics of myokinase. J. Biol. Chem. 243, $3963=3972$.

\author{
Dr. Ulrich Fauth \\ Klinik für Anästhesiologie \\ Langenbeckstraße 1 \\ D-6500 Mainz \\ Bundesrepublik Deutschland
}

